TECHNICAL TRANSACTIONS 2/2017

CZASOPISMO TECHNICZNE 2/2017

Mechanics

DOI: $10.4467 / 2353737$ XCT.17.024.6217

\author{
Zygmunt Domagała \\ Krzysztof Kędzia (krzysztof.kedzia@pwr.edu.pl) \\ Department of Operation and Maintenance of Logistics, Transportation and Hydraulic \\ Systems, Mechanical Faculty, Wroclaw University of Science and Technology
}

\title{
ANALYSIS, MODELLING AND VERIFICATION OF THE PHENOMENA \\ OCCURRING IN A HYDRAULIC PROP DURING DYNAMIC LOAD
}

ANALIZA, MODELOWANIE I WERYFIKACJA ZJAWISK ZACHODZĄCYCH

W DWUTELESKOPOWYM STOJAKU HYDRAULICZNYM W WARUNKACH

OBCIĄŻEŃ DYNAMICZNYCH

\begin{abstract}
The paper describes the working conditions of hydraulic prop in particular issues related to their dynamics. On this basis, mathematical model was developed for given simplifying assumptions. The paper includes description of simulation model as well as an experimental verification performed in HSW Stalowa Wola.

Keywords: hydraulic prop, simulation model, experimental verification
\end{abstract}

\section{Streszczenie}

W artykule opisano warunki pracy podpory hydraulicznej, w szczególności zagadnienia związane z ich dynamiką. Na tej podstawie opracowano model matematyczny dla podanych założeń upraszczających. Praca zawiera opis modelu symulacyjnego, jak również weryfikację doświadczalną wykonaną w HSW Stalowa Wola.

Słowa kluczowe: podpora hydrauliczna, badania symulacyjne, weryfikacja eksperymentalna 


\section{Introduction}

Because of the lack of substantial reserves of such energy carriers as crude oil or natural gas within the borders of Poland, hard coal is the primary energy source in this country. Hard coal is mined underground using longwall systems, this contributes to movements of rock mass and therefore poses a direct danger to human life. Consequently, designers of mining machinery must constantly seek solutions that ensure the required levels of productivity whilst guaranteeing the maximum safety of miners. Longwall coal bed extraction systems are commonly used to protect tunnels and work spaces that have been newly created by mining. Thanks to the development of such systems, coal can be mined from ever deeper coal beds where the rock mass is more active $[3,5]$.

Currently, the danger of rockburst is present in about half of all active longwalls, generating a high demand for additional protective measures capable of taking the dynamic loads produced by rockbursts. Since such loads are often heavier than the static loads, they can damage or destroy the roof support.

It is difficult to prevent rock mass tremors because the manner in which they occur is not sufficiently understood and because of the short duration and their unpredictable nature. Since the opportunities to measure rockbursts in the mine heading are limited, the rockbursting phenomenon is evaluated on the basis of its effects. Investigations in mine conditions pose many difficulties and involve high costs connected with the use of specialist equipment; therefore, instead of carrying out investigations in mine conditions, roof support components are tested on a special test stand. Such testing is highly complex in order to reproduce the actual load present in the rock mass. Experimental studies are supplemented with low-cost (not requiring specialist equipment) analytical studies. However, the results of the latter may contain errors stemming from the adopted model and from the simplified assumptions [2].

Under the action of the rock mass force, the commonly used double telescopic roof supports undergo damage mainly due to the cracking of the second-stage cylinders. This observation provided the basis for analytical and experimental studies of a double-telescopic hydraulic prop equipped with release valves in its two stages. A schematic of such a solution is shown in Fig. 1.

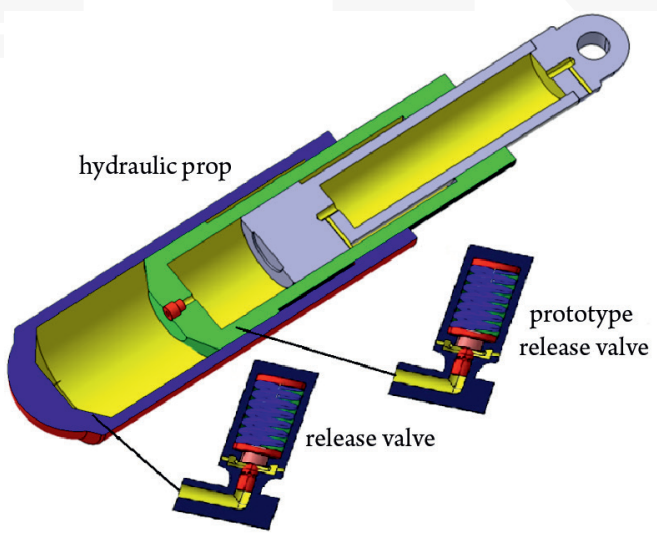

Fig. 1. Simplified schematic of hydraulic prop - concept (source: own work) 
A hydraulic press (shown in Fig. 2) was used in the experimental studies, during which, the tested support was loaded for a specified period of time.

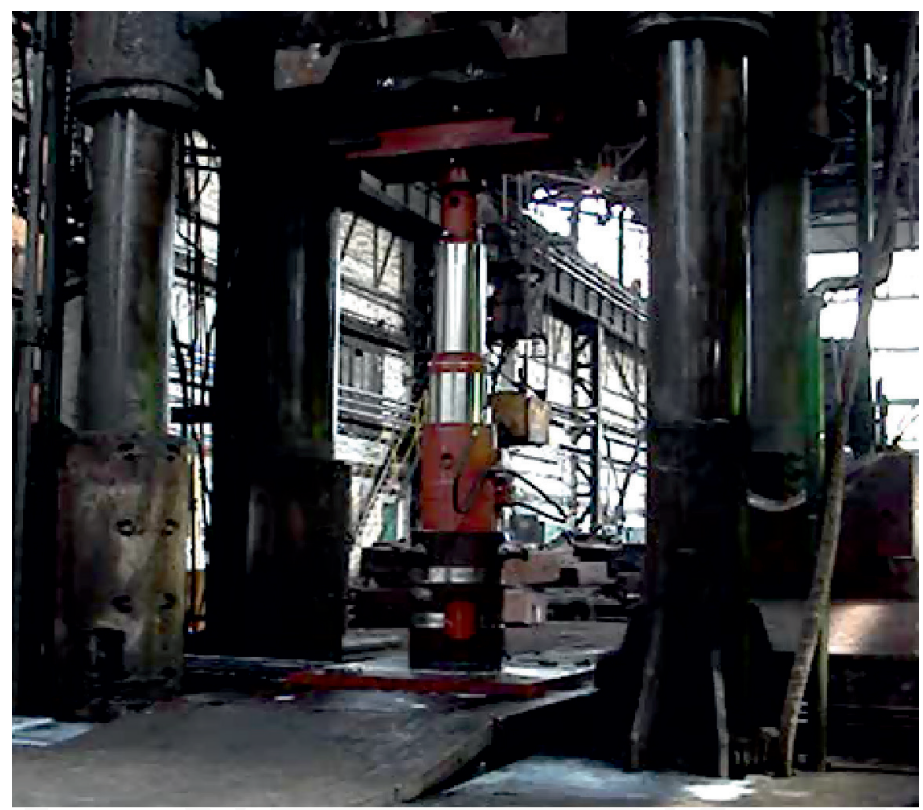

Fig. 2. Tests of actuators in a hydraulic press [2]

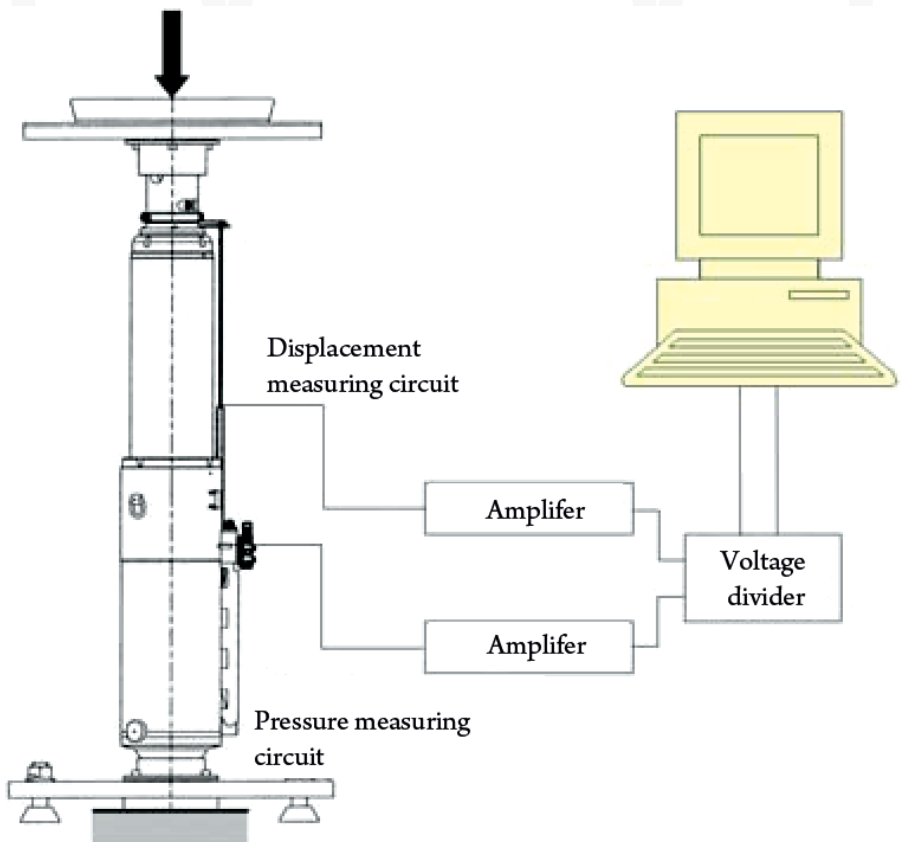

Fig. 3. Schematic of measuring system used for verification measurements of telescopic actuators [2] 
Thus far, the phenomena arising in the rock mass have been difficult or virtually impossible to predict, thus, they cannot be effectively prevented. Additionally, the short duration of the tremor is unhelpful in determining and recording the place where the latter occurred. The tests of the telescopic actuators in the hydraulic press merely showed that the actuators performed well under the given load and load duration.

\section{Mathematical model}

A mathematical model was built assuming the discrete distribution of mass and elasticity and taking into account the constraints stemming from the MATLAB-Simulink software used for the computations. The hydraulic system of a powered roof support consists of many components such as actuators, flexible pipes, a pump, a tank and a valve block. The number of system components was considerably reduced in order to simplify the mathematical model and the simulation model. A schematic of the modelled hydraulic system is shown in Fig. 1. The symbols describing the hydraulic prop in Fig. 4 were used to formulate mathematical equations.

\subsection{Equations of forces acting on hydraulic prop}

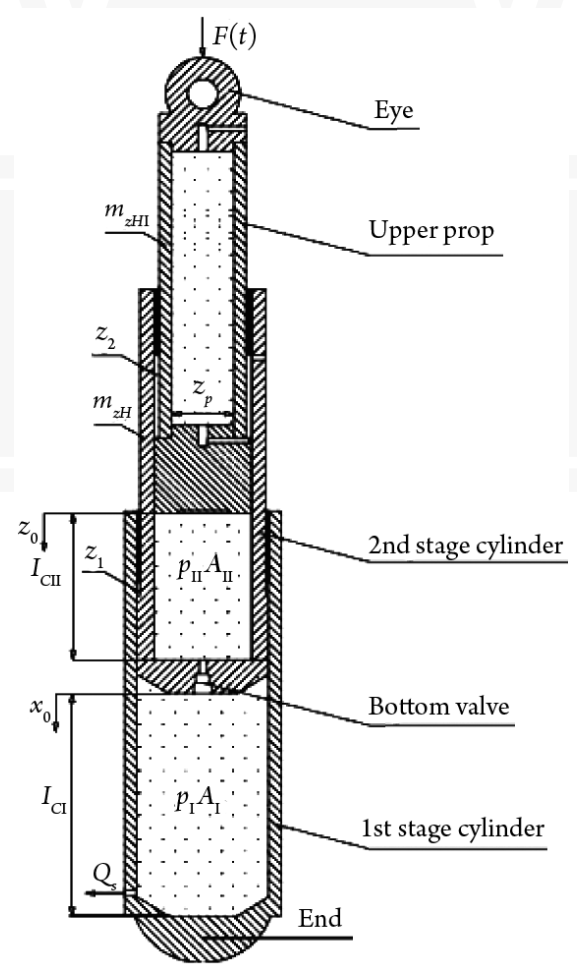

Fig. 4. Hydraulic prop (source: own work) 
The equations of the forces acting on the particular stages of the hydraulic prop are as follows:

where:

$$
\begin{gathered}
F(t)-F_{s b \mathrm{II}}-F_{s t \mathrm{II}}-F_{s h \mathrm{II}}=0 \\
P_{\mathrm{II}}\left(A_{\mathrm{II}}-A_{d}\right)-F_{s b \mathrm{I}}-F_{s t \mathrm{I}}-F_{s h \mathrm{I}}=0
\end{gathered}
$$

$F_{s b}$ - the prop's force of inertia, including mass $\mathrm{m}$,

$F_{s t}$ - the viscous friction force,

$F_{s h}$ - the force exerted by pressure onto the piston surface,

$F(t)$ - the rock mass impact force.

Equations (1) and (2) are considered for the following initial conditions:

$$
x=x_{g r}, \frac{d x}{d t}=0, \frac{d^{2} x}{d t^{2}}=0, z=0, \frac{d z}{d t}=0, \frac{d^{2} z}{d t^{2}}=0
$$

and for the following boundary conditions:

$$
x=x_{g r}, \frac{d x}{d t}=0, \frac{d^{2} x}{d t^{2}}=0, z=g r, \frac{d z}{d t}=0, \frac{d^{2} z}{d t^{2}}=0
$$

\subsection{Equation of forces acting on head of release valve I}

Figure 5 schematically shows the prop's $1^{\text {st }}$ stage release valve. The symbols describing the valve in the figure below were used to formulate the mathematical equations.

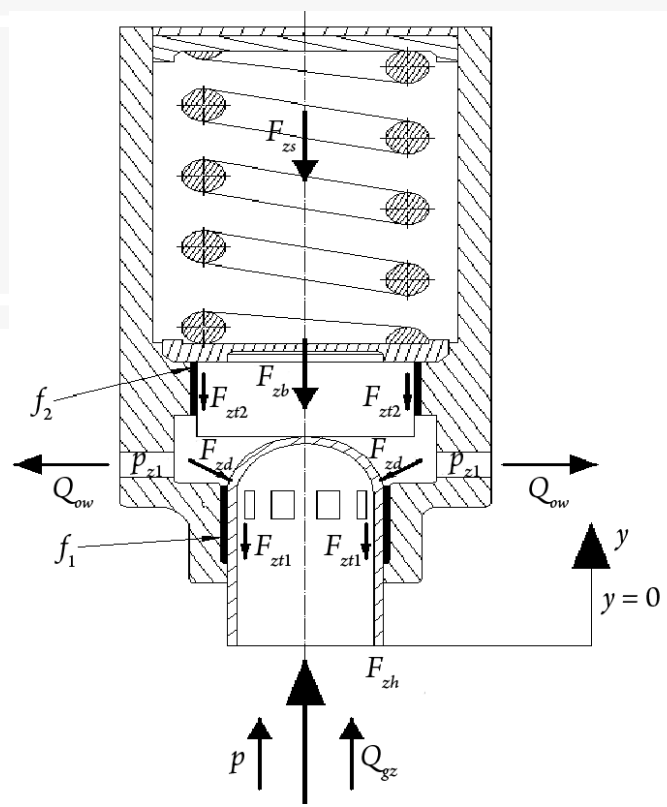

Fig. 5. Schematic of valve (source: own work) 
The equation of the forces acting on the head of release valve I is as follows:

where:

$$
F_{z h}-F_{z b}-F_{z t}-F_{z s}-F_{z d}=0
$$

$F_{z h}$ - the force exerted by pressure onto the valve head;

$F_{z b}$ - the force of inertia;

$F_{z t}-$ the force of viscous friction;

$F_{z s}$ - the force produced by spring deflection;

$F_{z d}$ - the hydrodynamic force.

The above equations are considered for the following initial conditions:

$$
y=0, \frac{d y}{d t}=0, \frac{d^{2} y}{d t^{2}}=0
$$

and for the following boundary conditions:

$$
y=y_{g r}, \frac{d y}{d t}=0, \frac{d^{2} y}{d t^{2}}=0
$$

\subsection{Equation of rate of flow through the valve under-head chamber}

where:

$$
Q_{g z}-Q_{c p}-Q_{g p}-Q_{w}=0
$$

$Q_{g z}$ - the rate of the flow through the valve head,

$Q_{c p}^{g z}$ - the flow rate resulting from the compressibility of the working liquid in the under-head chamber,

$Q_{g p}$ - the flow rate resulting from the displacement of the valve head,

$Q_{w}$ - the rate of the flow through the valve under-head chamber.

The equation of forces and the equation of flow rates for the 2 nd stage release valve are the same as for the $1^{\text {st }}$ stage release valve.

\subsection{Equation of rates of flow in the modelled system}

Figure 6 shows a schematic of the modelled hydraulic system, including the adopted symbols.

For the above schematic, the following equations of flow were derived:

where:

$$
\begin{aligned}
& Q_{s 1}-Q_{g z 1}-Q_{c 1}-Q_{g 1}=0 \\
& Q_{s 2}-Q_{g z 2}-Q_{c 2}-Q_{g 2}=0
\end{aligned}
$$

$Q_{s}$ - the liquid flow rate resulting from the movement of the upper prop,

$Q_{c}$ - the rate of flow of the liquid resulting from its compressibility under the prop's piston, 
$Q_{g}$ - the liquid flow rate resulting from the displacement of the valve head,

$Q_{g z}$ - the rate of the flow through the valve head.

The equation of forces and the equation of flow rates for the 2 nd stage release valve are the same as for the $1^{\text {st }}$ stage release valve.

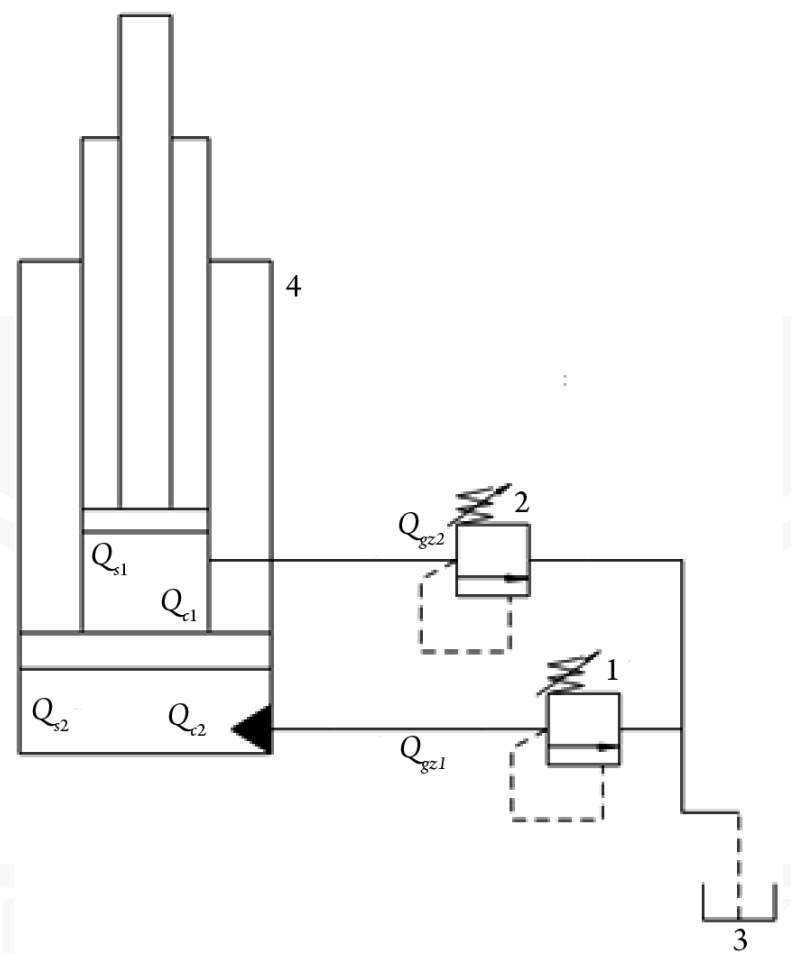

Fig. 6. Schematic of modelled hydraulic system, including adopted symbols (source: own work)

\subsection{Mathematical model of hydraulic press}

Equations of forces and flow rates characterising the hydraulic press are presented below. Figure 7 shows a schematic of the modelled press.

The equation of the forces acting on the hydraulic press is as follows:

where:

$$
F_{p h}-F_{p b}-F_{p t}-F_{s h 2}=0
$$

$F_{p h}$ - the force exerted by pressure onto the press piston,

$F_{p b}$ - the force of inertia of the hydraulic press,

$F_{p t}$ - the force of viscous friction,

$F_{s h 2}$ - the force of support in the 2 nd stage of the actuator. 


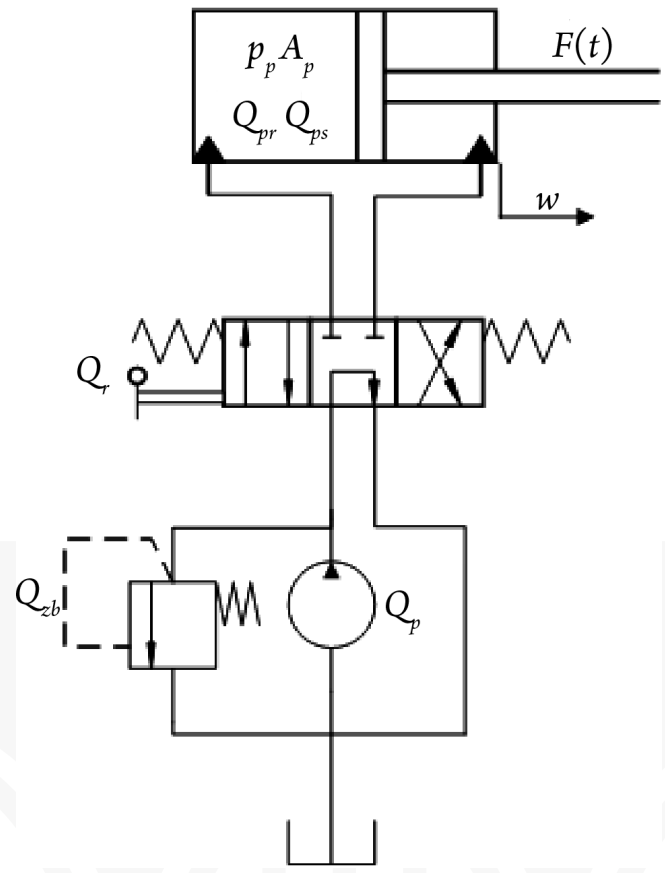

Fig. 7. Schematic of modelled hydraulic press (source: own work)

\subsection{Equations of flow rates in the hydraulic press}

The equations describing the balance of flow rates in the hydraulic press are as follows:

where:

$$
\begin{gathered}
Q_{p}-Q_{p p}-Q_{r}-Q_{c b}=0 \\
Q_{r}-Q_{p s}-Q_{p r}=0
\end{gathered}
$$

$Q_{p}$ - the rate of delivery of the pump,

$Q_{p p}$ - the rate of flow of the liquid resulting from its compressibility in the conduit between the pump and the distributor,

$Q_{\text {- }}$ - the rate of flow of the liquid through the distributor,

$Q_{z b}$ - the flow rate resulting from the flow of the liquid through the safety valve,

$Q_{p s}$ - the rate of flow of the liquid resulting from its compressibility under the press piston,

$Q_{p r}$ - the flow rate resulting from the displacement of the hydraulic press piston.

The MathWorks Matlab software environment was used to conduct simulation studies. The software enables one to perform numerical computations, test algorithms, modelling, run simulations and analysis, and visualisations of data. 


\section{Verification of mathematical model}

Verification was performed by comparing the experimental graphs of pressure in the 2nd stage cylinder and of 2 nd stage upper prop displacement with the respective graphs obtained from simulations.

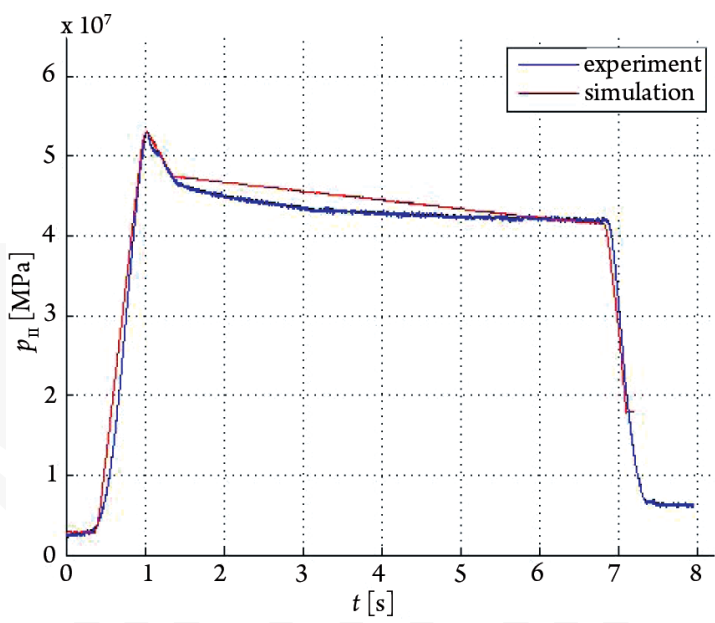

Fig. 8. Graphs of pressure in 2nd stage of hydraulic prop - test (41), modified model (source: own work)

Figure 8 shows exemplary experimental and simulated pressure curves for the hydraulic press. By comparing the curves, one can evaluate the validity of both the mathematical model and the simulation model of the investigated hydraulic system. The figure indicates that there are no grounds for rejecting the mathematical model. However, the experiment did not reproduce the actual conditions of the hydraulic work of the pit prop; therefore, in the simulation model, the loading of the prop by the hydraulic press was replaced by a force loading a single prop in accordance with the relation given by Stoiński [6].

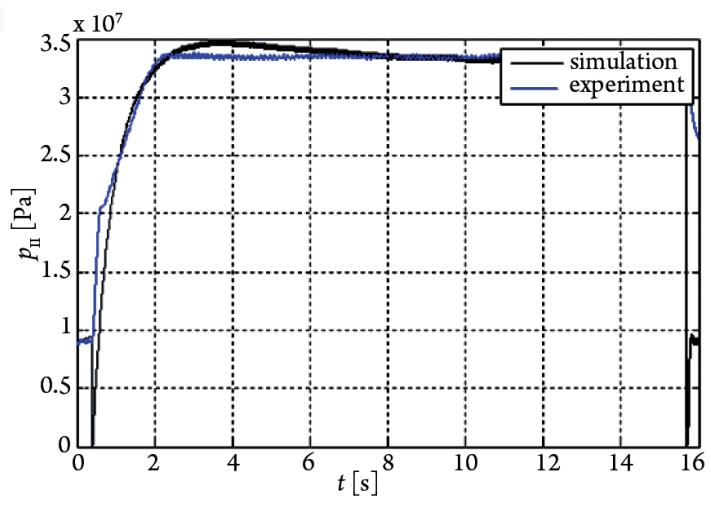

Fig. 9. Graphs of pressure in chamber under upper prop - test (25), modified model (source: own work) 


\section{Mathematical model of rock mass load}

If the effect of the dynamic impact of the rock mass on the roof support is assumed to be a consequence of the instantaneous increase in load brought about by a rockburst, and if it is assumed that the particular sections of the roof support are uniformly loaded, the force loading a single prop can be expressed by the relation [6]:

$$
f(t)=F_{w}+F_{d}\left[1+k_{d} \cdot e^{-\delta t} \sin (\omega t-\varphi)\right]
$$

where:

$F_{w}$ - the initial supporting power of the prop, $[\mathrm{N}]$,

$F_{d}$ the force additionally loading the prop, $[\mathrm{N}]$,

$$
\begin{aligned}
& k_{d}=0.102 \omega v_{0}-\text { a factor of safety }\left[\frac{\mathrm{m}}{\mathrm{s}^{2}}\right], \\
& \omega=3.13 \sqrt{\frac{k_{s}}{\eta_{t z} F_{r}}} \text { - the angular frequency of the vibrating system, }\left[\mathrm{s}^{-1}\right] \\
& \delta \text { - the damping coefficient of the vibrating system, }\left[\mathrm{s}^{-1}\right] .
\end{aligned}
$$

\section{Simulation studies}

The aim of the simulation studies was to minimise the pressures generated by an excitation in the individual sections of the hydraulic prop. The excitation represents an actual rockburst. The graph of the load generated by an exemplary rockburst is shown in the figure below.

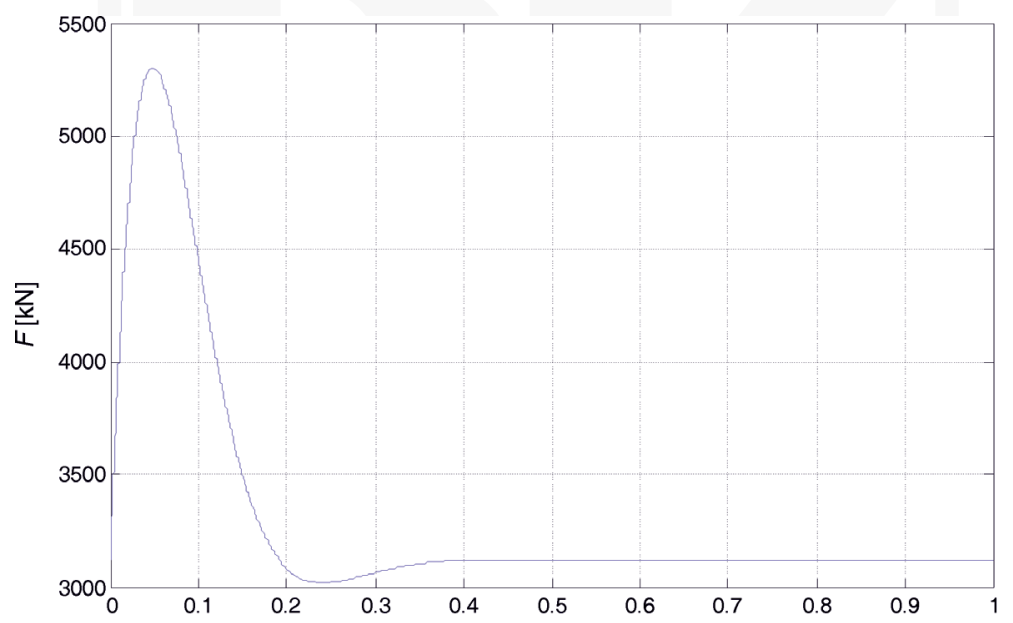

Fig. 10. Graph of load generated by rockburst (source: own work)

The distinctive feature of the considered rockburst is the fact that the maximum load values are reached in $0.05 \mathrm{~s}$ and they are nearly twice as high as the stable force value reached 
in $0.4 \mathrm{~s}$. This means that tests of hydraulic props performed through the use of a hydraulic press do not reproduce the conditions prevailing during the rapid collapse of the rock mass in a rockburst. The very heavy instantaneous loading of the pit prop results in an increase in pressure increment $\mathrm{dp} / \mathrm{dt}$ whereby the pressure in the cylinders of the hydraulic actuators rapidly rises. In such conditions, the pressure exceeds the allowable pressure (Table 1) and the hydraulic prop cracks.

The considered hydraulic prop includes release (safety) valves which should open and release some of the emulsion in order to reduce the pressure in the actuators; however, the rate of pressure rise is so fast and the time in which the pressure reaches its maximum is so short that the release valve cannot open, as a result, the prop fails.

The question that thus arises is whether or not the release valve would open under the same load if the rate of pressure rise in the hydraulic system of the pit prop could be reduced.

An analysis of the problem showed that this is possible and can be achieved, for example, by:

- changing the initial tension of the spring of the release valves;

- changing the stiffness of the spring;

- increasing the volume of the hydraulic system.

Studies were carried out on this problem using a simulation model which had been successfully validated on a real object in HSW (Stalowa Wola Steel Mill).

First, the effect of the initial tension of the spring in the 2nd stage cylinder valve was studied. The results of this study are presented in Fig. 11.

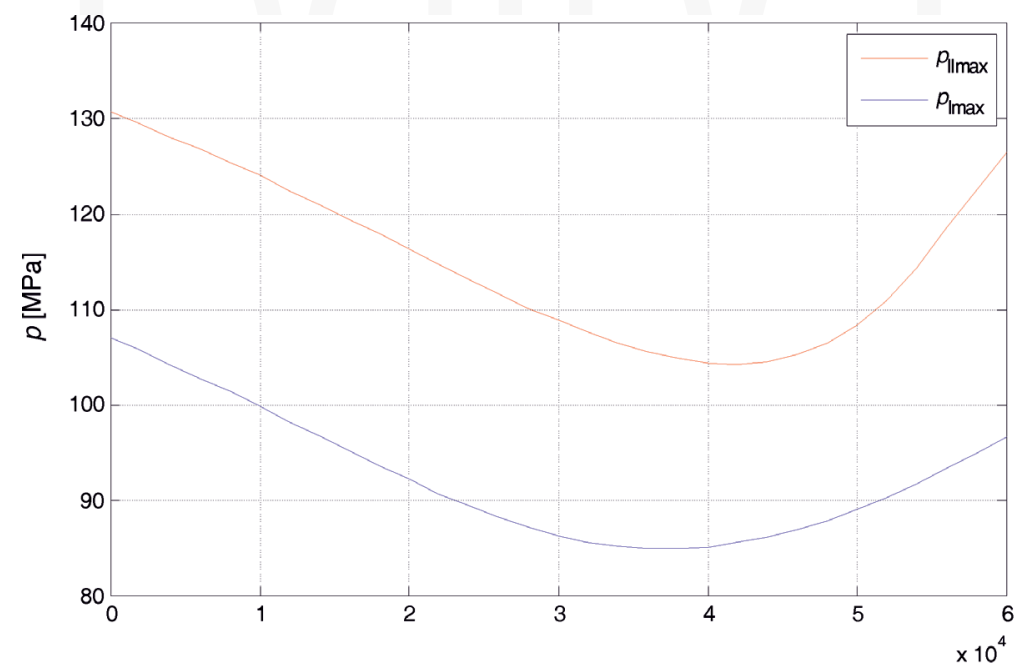

Fig. 11. Effect of initial spring tension $c_{02}$ on maximum pressures in particular prop stages (source: own work)

Figure 11 shows that there exist such initial spring tensions at which pressures in the individual sections of the pit prop reach minimal values. The minimal pressures are reached at $c_{02}=42000 \mathrm{~N}$ for the actuator's second stage and at $c_{02}=37000 \mathrm{~N}$ for its first stage; however, the pressures reached are higher than those allowable for this actuator structure. 


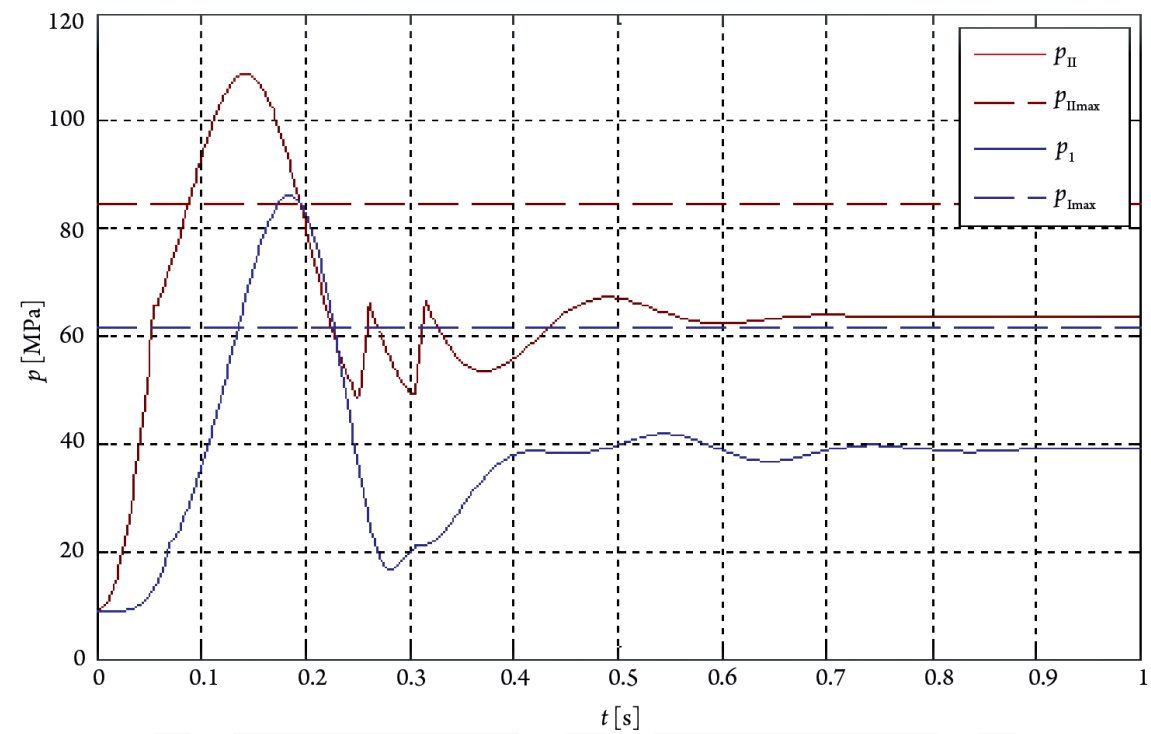

Fig. 12. Pressure curves for $c_{02}=42000 \mathrm{~N}$ (source: own work) $\left(P_{\text {allow }}\right)$

Figure 12 shows pressure curves for spring tension $c_{02}=42000 \mathrm{~N}$. It is clearly apparent that the pressures in both prop stages exceed the allowable values.

Another factor which can affect the performance of the system is the stiffness of the release valves' springs.

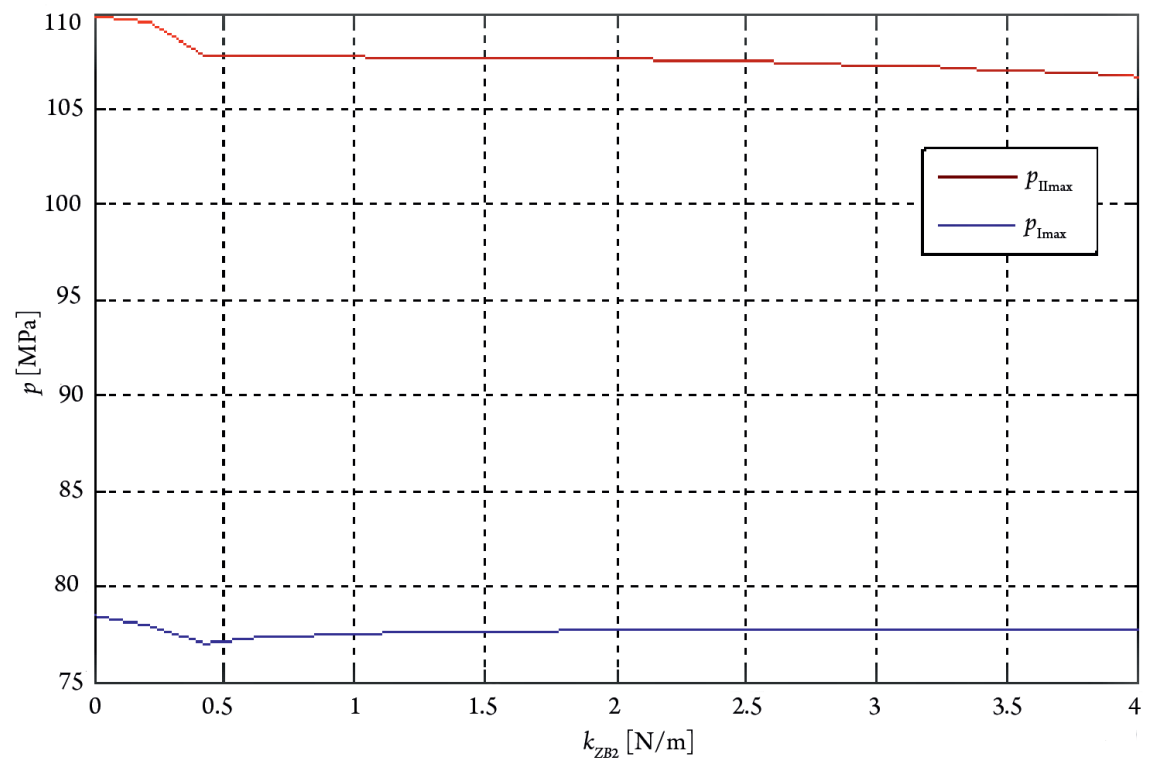

Fig. 13. Effect of initial spring stiffness $k_{z S 2}$ on maximum pressures in individual prop sections (source: own work) 
Figure 13 shows that the stiffness of the 2 nd stage valve spring has no so strong effect on the maximum pressures as it had at the initial tension of this spring. The lowest pressures in the 2nd stage cylinder occurred at maximum adopted stiffness $k_{z<2}=4 \cdot 10^{6} \mathrm{~N} / \mathrm{m}$.

The simulation model was then used to determine the effect of the initial spring tension for the first stage valve. The results are presented in Fig. 14.

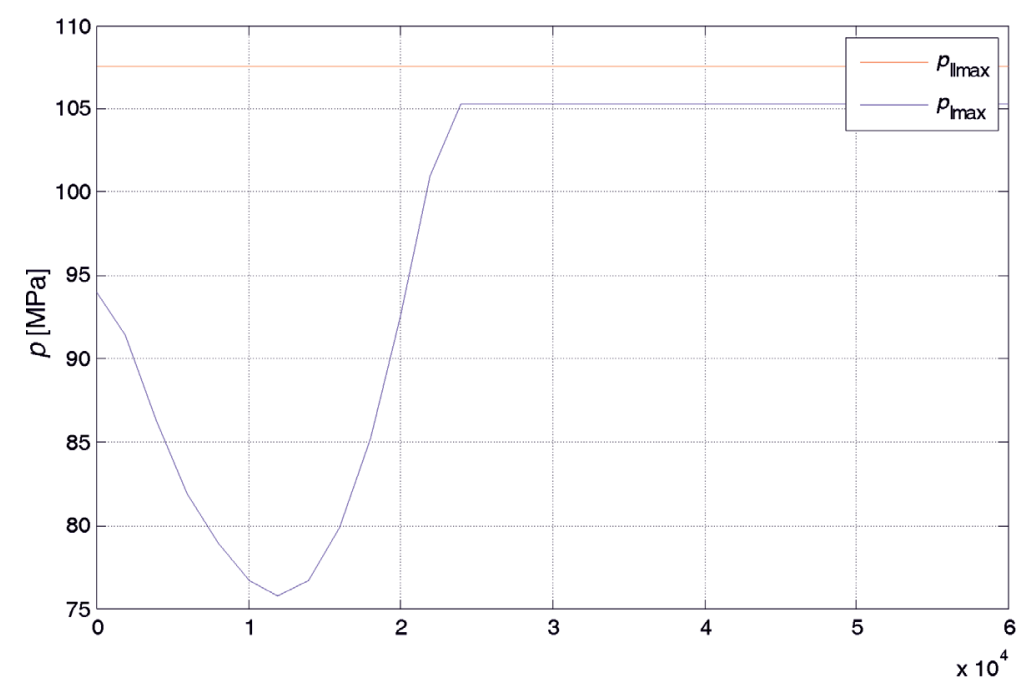

Fig. 14. Effect of initial spring tension $c_{01}$ on maximum pressures in particular prop stages (source: own work)

It is immediately apparent that the initial tension of the spring in the $1^{\text {st }}$ stage valve has no effect whatsoever on the maximum pressures in the second stage of the cylinder.

In the case of the cylinder's first stage, the best parameters were obtained for $c_{01}=12000 \mathrm{~N}$; however, the pressures are still higher than those allowable for the $1^{\text {st }}$ stage cylinder.

Finally, the effect of the hydraulic system volume on pressure curves and on the maximum pressures was examined. A change in system volume undoubtedly has an effect on the rate of pressure rise (dp/dt); however, the drawback of this solution is that it entails an increase in the overall dimensions of the system. The most effective solution is to use hydraulic accumulators. Figure 15 shows the effect of the capacity of a hydro-pneumatic accumulator on the maximum pressures in the individual sections of the prop.

Figure 15 indicates that different ranges of accumulator volume have different effects on the performance of the system. The horizontal broken lines mark the allowable pressure values. The red lines and the blue lines represent the maximum pressures as a function of hydraulic accumulator volume for the $2 \mathrm{nd}$ stage and the $1^{\text {st }}$ stage of the telescopic prop, respectively.

The figure shows that for a hydraulic accumulator volume of 100 litres. the pressures in the hydraulic prop do not exceed the allowable values. This problem is better illustrated in Fig. 16 where the pressure curves for the hydraulic support with and without a hydraulic accumulator are compared. 


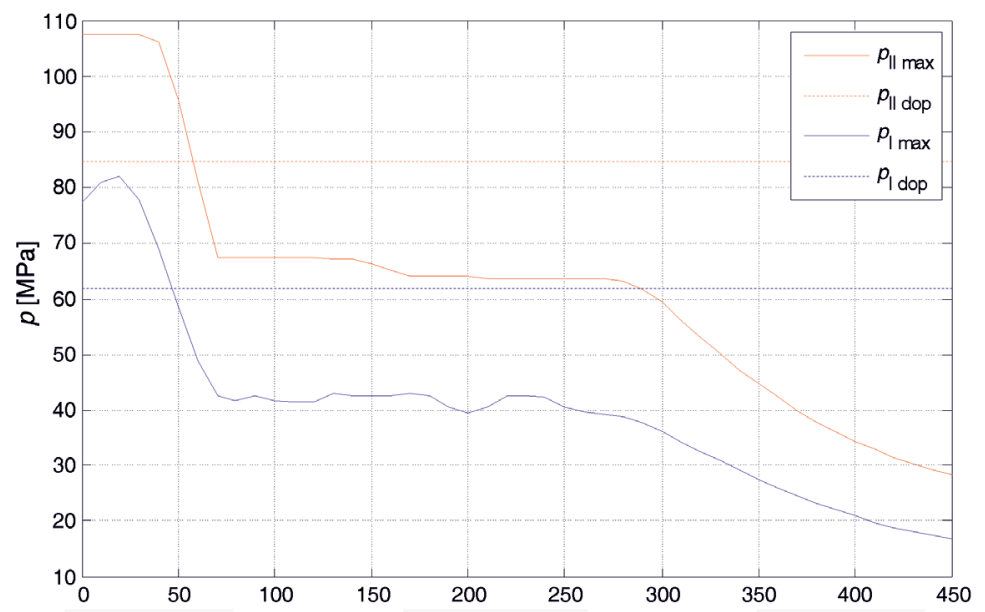

Fig. 15. Effect of hydro-pneumatic accumulator capacity on maximum pressures in particular prop stages [4]

The graphs indicate that the accumulator with the assumed volume was able to offset the whole rapid pressure rise and therefore reduce the rate of pressure increment $\mathrm{dp} / \mathrm{dt}$.

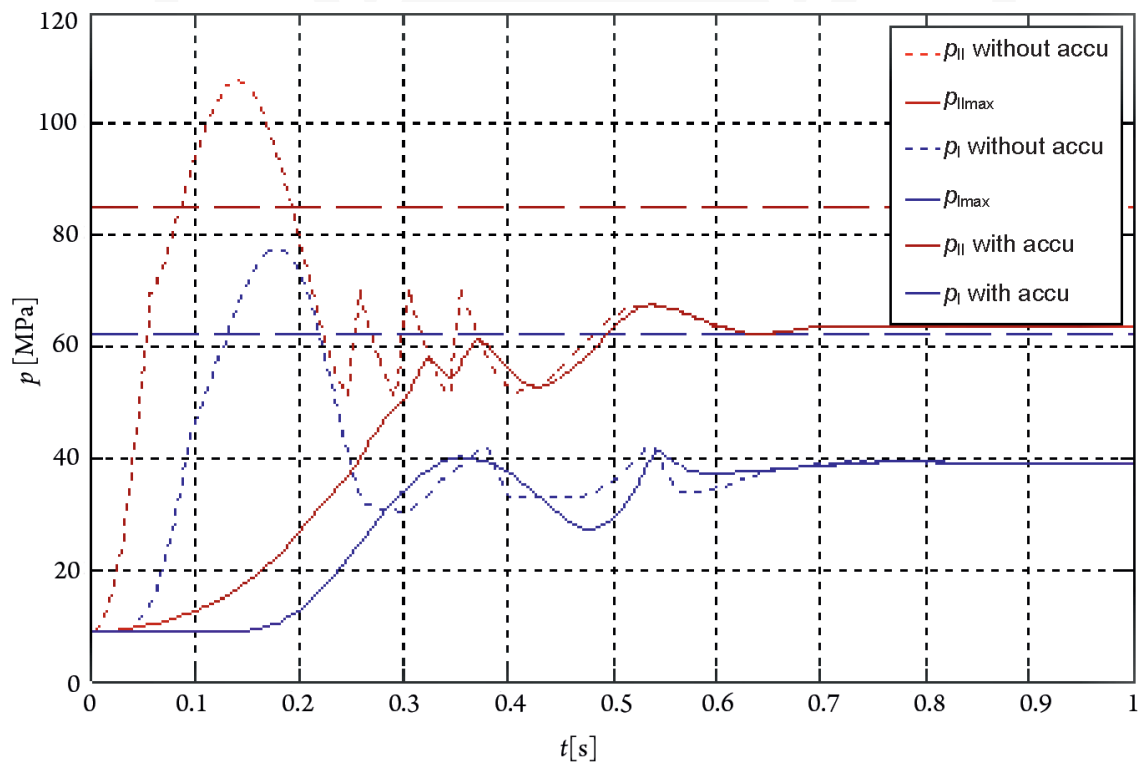

Fig. 16. Pressure curves for $V_{0 a}=100 l$ (source: own work) 


\section{Conclusions}

The simulation studies show that a change in the valve spring parameters had no significant effect on the maximum pressure values, whereas the use of a hydraulic accumulator could significantly offset the maximum pressures in the individual sections of the hydraulic prop and consequently protect the cylinders of the sections from destruction.

The use of hydraulic accumulators in roof support props can solve the problem of the hydraulic blockage of the release valves. This phenomenon is a serious problem due to the fact that as the supporting power of hydraulic props increases, so do their diameters and consequently, the volume of working liquid under the piston. Currently, the valves are not able to release the proper amount of working liquid in a sufficiently short time to ensure the required collapse of the prop. A hydraulic accumulator is suitable for this purpose since it takes over the working liquid excess and prevents the prop from being destroyed.

\section{References}

[1] Domagała Z., Modelowanie i symulacja zjawisk zachodzacych $w$ zmechanizowanej obudowie ścianowej, Maszyny Górnicze 4/2009.

[2] Domagała Z, Marianowski J., Modelowanie i weryfikacja zjawisk dynamicznych zachodzacych w teleskopowych stojakach hydraulicznych, Badanie, konstrukcja, wytwarzanie i eksploatacja układów hydraulicznych, Gliwice 2013.

[3] Jaszczuk M., Ścianowe systemy mechanizacyjne, Śląsk, Wydawnictwo Naukowe, Katowice 2007.

[4] Kamiński G., Analiza zjawisk dynamicznych zachodzacych w dwuteleskopowym stojaku hydraulicznym, Wrocław 2015.

[5] Praca zbiorowa, Nowoczesne, niezawodne i bezpieczne systemy mechanizacyjne dla górnictwa, Centrum Mechanizacji Górnictwa KOMAG, Gliwice 2008.

[6] Praca zbiorowa do redakcją A. Kidybańskiego, Stateczność górotworu i obudowy przy łącznym obciążeniu statycznym i dynamicznym, Główny Instytut Górnictwa, Katowice 2009.

[7] Stoiński K., Obudowy górnicze w warunkach zagrożenia wstrząsami górotworu, Główny Instytut Górnictwa, Katowice 2000.

[8] Stryczek S., Układy hydrauliczne Tom I. Elementy i Tom II Układy, Wydawnictwo Naukowo-Techniczne, Warszawa 2005. 


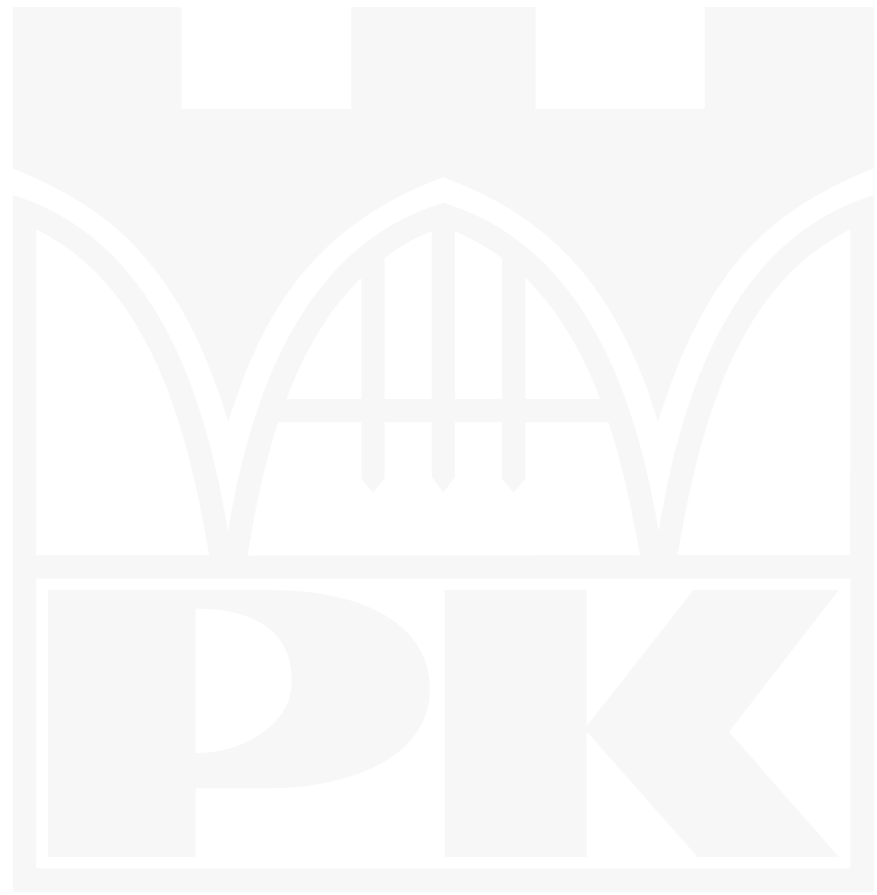

